\title{
Vitamin D Deficiency and Associated Factors in Adult Females of Chattogram
}

\author{
Shaheda Ahmed ${ }^{1 *}$ \\ Mohammed Jalal Uddin ${ }^{2}$ \\ Nayeema Tasnim ${ }^{3}$
}

'Department of Biochemistry Chattagram International Medical College Chattogram, Bangladesh.

${ }^{2}$ Department of Community Medicine Chattogram Maa-O-Shishu Hospital Medical College Chattogram, Bangladesh.

${ }^{3}$ Department of Biochemistry Chittagong Medical College Chattogram, Bangladesh.

\author{
*Correspondence to: \\ Dr. Shaheda Ahmed \\ Associate Professor \\ Department of Biochemistry \\ Chattagram International Medical College \\ Chattogram, Bangladesh. \\ Mobile : +8801715704218 \\ Email : perveen71@gmail.com
}

Date of Submission $\quad: \quad 11.05 .2021$
Date of Acceptance

www.banglajol.info/index.php/CMOSHMCJ

\begin{abstract}
Background : Vitamin D is an essential nutrient and deficiency of it leads to devastating disorders. This study aimed to find out the associated factors with selected variables of low vitamin D among adult females of Chattogram.
\end{abstract}

Materials and methods : Cross-sectional observational study was conducted from September 2019 to February 2020 at a diagnostic complex of Chattogram. Participants were adult females of Chattogram. All participants gave oral informed consent and answered a questionnaire that included 16 questions covering demographic information, monthly income, educational status, occupation, body weight, duration of sun exposure, dress pattern (Using hijab or burkha, regular dress-up) drug and disease history. Blood samples were collected by cautious aseptic procedure. Serum vitamin $D$ levels were measured by using immunoassay method. Adult females of Chattogram with no religious restrictions, $n=150$, aged 31 to 70 years.

Results: Overall, $88 \%$ had low vitamin D levels with deficient $60.66 \%$ and insufficient 27.34\%. Sufficient level of vitamin D was found only among $12 \%$. The prevalence of vitamin $D$ deficiency was much higher in females with house-wife status $73.33 \%$ ( $p$ value of 0.0001 ) wearing hijab $46.66 \%$ ( $p$ value of 0.001 ). It could be due to interference with UVB radiation into skin, short duration of sun exposure, use of sunblock cream or less supplementary intake.

Conclusion : Vitamin D deficiency is an emerging but neglected health issue in modern time, particularly more vulnerable are female population. Ironically, abundant sunlight of Bangladesh seems failed to protect the self-imposed concrete prisoner, classically known as home-makers, and practitioner of indoor life style that leads to avoidance of sun light. However, large sample size is mandatory to boost-up the findings of current study.

Key-words: Chattogram; Females; Vitamin D deficiency.

\section{INTRODUCTION}

There are two forms of vitamin D, Vitamin $\mathrm{D}_{2}$ (Ergocalciferol) and Vitamin $\mathrm{D}_{3}$ (Cholecalciferol). Vitamin $\mathrm{D}_{3}$ is derived from ultraviolet sunlight exposure or from oily fish or supplements ${ }^{1,2}$. Vitamin D, that is synthesized in skin needs two steps of hydroxylation in the liver and kidney to form the biologically active form of vitamin $\mathrm{D}, 1,25(\mathrm{OH})_{2} \mathrm{D}^{2}$. 1,25 - dihydroxy cholecalciferol (Calcitriol) binds to Vitamin D Receptors (VDRs) that are sited in many cells of the body, and then it is ready for biological action ${ }^{3}$.

Vitamin D is the essential nutrient needed very much for regulation of calcium and phosphorous. Intestinal calcium absorption is eventually facilitating bone mineralization ${ }^{4}$. It helps in regulation of muscular strength and function ${ }^{5}$. It also strengthen immunity ${ }^{6}$. It is vital for inhibition of cellular proliferation and induction of terminal differentiation, inhibition of angiogenesis, stimulation of insulin production, inhibition of renin production and stimulation of macrophage cathelicidin production ${ }^{7}$. 
Vitamin D deficiency is now acknowledged as a common health problem for general population ${ }^{8}$. Deficiency of Vitamin D plays a vital role in metabolic bone disorders such as osteomalacia in adults and rickets in children ${ }^{9}$. Low levels of vitamin D is related to many chronic diseases such as autoimmune diseases, cardiovascular diseases, hypertension, diabetes mellitus, metabolic syndrome, depression, cancer, neurocognitive function and increased susceptibility to infection ${ }^{10}$.

According to the National Osteoporosis Foundation (NOF) vitamin $\mathrm{D}$ requirement for adults under the age of 50 is $400-$ $800 \mathrm{IU} /$ day and age 50 and above is $800-1000 \mathrm{IU} /$ day $^{11}$. Majority agree that a Vitamin D concentration less than 50 $\mathrm{nmol} / \mathrm{L}$ or $20 \mathrm{ng} / \mathrm{ml}$ is an indication of vitamin D deficiency, 51 - $74 \mathrm{nmol} / \mathrm{L}$ or $21-29 \mathrm{ng} / \mathrm{ml}$ is considered as insufficiency and $30 \mathrm{ng} / \mathrm{ml}$ or more indicates sufficiency ${ }^{12}$. Vitamin D intoxication usually does not happen until the level reaches up to $150 \mathrm{ng} / \mathrm{ml}^{13}$.

Main source of vitamin D is exposure of the skin to sunlight(ultra violet $\mathrm{A}$ rays and ultra violet $\mathrm{B}$ rays), under normal condition skin is able to supply $80-100 \%$ of vitamin D requirement of body ${ }^{11}$. Exposure of the skin to sunlight usually between $1000 \mathrm{~h}$ and $1500 \mathrm{~h}$ in the spring, summer and fall is sufficient to produce vitamin D. Vitamin D produced in the skin may remain in the blood for a longer time than the ingested vitamin D (At least twice the duration). ${ }^{3}$ In tropical country like Bangladesh, during summer time exposure to sunlight for about $10-15$ minutes per day, two to three times per week is adequate for effective vitamin $\mathrm{D}$ formation in the $\operatorname{skin}^{11}$. Other studies proved that human body can intake most of their vitamin D requirement from 5 - 30 minutes of direct sunlight when sun is at high in position ${ }^{14}$.

Consumed animal products such as salmon, tuna, sardines, fish liver oils, beef liver, cheese, egg yolks contain vitamin $\mathrm{D}^{15}$. Some foods such as milk, soy or rice beverage, yogurt and cheese are fortified with vitamin $\mathrm{D}^{16}$.

Skin derived synthesis of vitamin D depends on pigmentation, latitude, season, clothing, age, sunscreen use and local weather conditions ${ }^{17}$. Anything that prevents penetration of sunlight into skin can reduce vitamin D synthesis in the skin. People live in norther half of the United states and Canada are at high risk of vitamin D deficiency, because their climate hinders production of sufficient sunlight. Vitamin D deficiency also found in sunny climates for many reasons, like wearing sun block, increased skin pigmentation, fat malabsorption syndrome, patient with nephrotic syndrome (Lose vitamin D through excretion of vitamin D- binding protein in the urine $)^{14}$. Drugs like antiseizure medications and long-term glucocorticoids use decreases serum vitamin D level ${ }^{18}$. Limited exposure to sunlight, covering whole body for religious or cultural reasons while outing (Religious dress for Muslim adult females) may result into limited exposure to sunlight ${ }^{19-21}$. Many studies have been conducted on Muslim females regarding this issue, and results found significant level of vitamin Dinsufficiency or deficiency $^{21-23}$.
This study was done to assess the vitamin D status among adult females of Chattogram and to evaluate the relation between vitamin D levels and duration of sunlight exposure, occupational identity, using religious dress that covers almost whole body (Except face and hands).

\section{MATERIALS AND METHODS}

A cross-sectional observational study was conducted from September 2019 to February 2020 at a diagnostic complex of Chattogram. Participants were adult females of Chattogram with no religious restrictions. Total respondents were 150, age between 31 and 70 years. All participants gave oral informed consent and answered a questionnaire that included 16 questions covering demographic information, monthly income, educational status, occupation, body weight, duration of sun exposure, dress pattern (Using hijab or burkha) drug and disease history. Blood samples were collected by cautious aseptic procedure. Serum vitamin D levels were measured by using immunoassay method. Data were managed with SPSS version 20 .

\section{Inclusion criteria:}

Patients with symptoms of no gross vitamin D deficiency, willing to participate in the study.

\section{Exclusion criteria:}

Patients with vitamin D supplementation or treatment, hepatic and renal impairment, congenital anomalies, malabsorption syndrome, pregnant and lactating mother.

\section{RESULTS}

Total number of respondents were 150, aged 31 to 70 years. 75 women with usual dress and 75 with burkha. Overall, $88 \%$ had low vitamin D levels with deficient $60.66 \%$ and insufficient $27.34 \%$. Sufficient level of vitamin D was found only among $12 \%$. The prevalence of vitamin D deficiency was much higher in females with house-wife status $73.33 \%$ (p value of 0.0001 ) wearing hijab $46.66 \%$ ( $p$ value of 0.001 ).

There was no significant association found between different age groups but religious norms like wearing hijab or covering whole body (Except face and hands) matters significantly [Table I].

Table I : Age of the Respondents

\begin{tabular}{lrrr} 
Age Group & Regular dress & $\begin{array}{r}\text { Whole body } \\
\text { covering attire }\end{array}$ & p value \\
over regular dress & \\
$31-40$ years & 33 & 28 & \\
$41-50$ years & 27 & 36 & $\mathrm{p}=0.68$ \\
$51-60$ years & 14 & 10 & \\
$61-70$ years & 01 & 01 & \\
\hline
\end{tabular}

Source: Study report 2020 
Major educational qualification among the respondents was at the stage of secondary to higher secondary level (Class X- XII) with the number of 59 out of 150 [Table II].

Table II : Educational status of the Respondents

\begin{tabular}{lcc} 
Grade & Regular dress & $\begin{array}{r}\text { Whole body covering } \\
\text { attire over regular dress }\end{array}$ \\
\hline$<$ Class X & 23 & 25 \\
Class X - XII & 32 & 27 \\
$>$ Class XII & 20 & 23
\end{tabular}

Source: Study report 2020

Regarding occupation, most of them were house wives with a percentage of $73.33 \%$, in this group majority preferred hijab for their outing with $\mathrm{p}$ value of 0.0001 . It is important in context to our study because their sun exposure was less than that of regular dressed-up group (Non-hijab group) [Table III].

Table III : Occupation of the Respondents

$\begin{array}{cl}\text { Occupation } \quad \text { Regular dress } & \begin{array}{l}\text { Whole body covering p value } \\ \text { attire over regular } \\ \text { dress }\end{array}\end{array}$

Home maker

or house wife

others

42

33

68

$\mathrm{p}=0.0001$

Source: Study report 2020

Monthly family income of the study population showed that majority of the families earned between 20,000 and 30,000 BTK per month. Family income of the women with regular outfits wasmore than the other group [Table IV].

Table IV : Monthly Family incomeof the Respondents

\begin{tabular}{lcc} 
Income & Regular dress & $\begin{array}{l}\text { Whole body covering } \\
\text { attire over regular dress }\end{array}$ \\
$<20,000$ BTK & 27 & 33 \\
$20,000-30,000$ BTk & 41 & 38 \\
$>30,000$ BTK & 07 & 04 \\
\hline
\end{tabular}

Source: Study reports 2020

Significant result showed in the table pointing vitamin D status of the respondents. Majority of them were suffering from vitamin D deficiency with the number of 62 out of total 150 . This group chose themselves to cover with religious clothing like hijab for their outdoor activities. It has been shownthat vitamin D level of whole body covering (except face and hands) group was less than the group wearing regular social get-up with $p$ value of 0.001 . It could be due to less sun exposure for their life style [Table V].
Table V : Vitamin D status of the Respondents

$\begin{array}{lcccc}\text { Vitamin D Status } & \begin{array}{r}\text { Regular } \\ \text { dress }\end{array} & \begin{array}{r}\text { Whole body } \\ \text { covering attire over } \\ \text { regular dress }\end{array} & \text { p value } \\ \text { Deficient } & 29 & 62 & \mathrm{p}=0.001 \\ \text { Insufficient } & 33 & 08 & \\ \text { Sufficient } & 13 & 05 & \end{array}$

Source: Study reports 2020

\section{DISCUSSION}

It is now well proved that low levels of vitamin D are linked with devastating disorders. Commonly reported factors associated with decreased vitamin D level are, higher skin pigmentation, less vitamin D fortified foods, cultural customs such as whole-body covering attire that leads to avoidance of direct exposure to sun light, low vitamin D supplementation ${ }^{24}$. Darker skin blocks UV radiation significantly and thereby decreases vitamin D production (People with dark skin may need 20-30 times as much exposure to sun light ${ }^{25}$. Excess adipose tissue of women than the men suggested to lower vitamin $\mathrm{D}$ concentration in female ${ }^{26}$.

In this study, total number of respondents were 150 , aged 31 to 70 years. Overall, $88 \%$ had low vitamin D levels with deficient $60.66 \%$ and insufficient $27.33 \%$. Sufficient level of vitamin D was found only among $12 \%$. The prevalence of vitamin D deficiency was much higher in females with house-wife status $73.33 \%$ ( $p$ value of 0.0001 ) wearing hijab $46.66 \%$ ( $p$ value of 0.001 ). There was a study among female students of UAE college which is consistent with our study. It recorded vitamin D deficiency among around $48 \%$ of the students, particularly in students wearing hijab, around $38 \%$, which might have interference with UVB radiation into the $\operatorname{skin}^{27}$. This problem could be due to avoidance or limited exposure to sunlight. The most suitable time for sun exposure for maximum vitamin D synthesis is between $10 \mathrm{am}$ and $1 \mathrm{pm}$. The use of sun blockers with variable sun protection factors (SPF $25-100)$ prevent the body's capability to synthesize vitamin D by approximately $93 \%$ to $99 \%{ }^{27}$. There are many studies linked with vitamin Ddeficiency in females wearing conservative clothes with a cover $^{28-31}$. Ultra-Orthodox Jewish women, who used to cover their heads for religious reasons, are also at high risk of vitamin $\mathrm{D}$ deficiency ${ }^{27}$. Only one study so far we found, that speaks totally opposite of these findings. This study found no significant difference of vitamin D levels between hijab users and non-users ${ }^{11}$. Vitamin D also acquired from natural dietary sources like fatty fish, fish oil and eggs, from fortified products (Such as milk and orange juice) and from supplements ${ }^{2}$. An earlier study found that up to $47 \%$ of vitamin D input may be from dietary supplements ${ }^{32}$. 
A Saudi Arabian study found that in spite of sufficient nutritional intake and regular exposure to UV sunlight, there were marked deficiency in serum vitamin D levels. It was explained by genetic predisposition to vitamin D deficiency among Saudi Arabians. This study also reported high prevalence of vitamin D deficiency in Asian population living in United Kingdom. So it is hypothesized that these is a genetic predisposition to vitamin D deficiency among Asians ${ }^{33}$. Vitamin D deficiency is highly prevalent in Pakistan, India, Bangladesh, Nepal, Sri Lanka, Myanmar and Bhutan due to their geographical and socioeconomic cultural similarity ${ }^{34,35}$.

Aforesaid problems can be solved with appropriate amount of vitamin D supplementation added with daily exposure to the Sunlight in the privately owned area, where there is no chance to breach religious restriction and by reducing the use of sunscreen while outing.

\section{CONCLUSION}

Our study is the continuation of the findings of many other previous studies those found significant vitamin D deficiency among adult women particularly due to less sun exposure that related to multiple factors like occupation, duration of sun exposure and life style in term of dress-up. But limitation of this study was small sample size. Large scale study is needed to establish the findings of the present study.

\section{DISCLOSURE}

All the authors declared no competing interest.

\section{REFERENCES}

1. Kulie T, Groff A, Redmer J, Hounshell J, Schrager S. Vitamin D: an evidence-based review. J Am Board Fam Med. 2009;22(6):698-706.

2. Holick M. Vitamin D deficiency. N Engl J Med. 2007;357:266-281.

3. Michael F, Holick Neil C, Binkley Heike A, Bischoff-Ferrari Catherine M, Gordon David A, Hanley Robert P, Heaney M, Hassan Murad and Connie M Weaver. Evaluation, Treatment and Prevention of Vitamin D Deficiency: an endocrine Society Clinical Practice guideline. J Clin Endocrinol Metab. 2011;96:1911-1930.

4. HuangC-H, HuangY-TA, LaiY-C, SunC-K. Prevalence and predictors of hypovitaminosis D among the elderly in subtropical region. July 2017. https://doi.org/10.1371/journal.pone.0181063.

5. Bischoff-Ferrari HA, Giovannucci E, Willett WC, Dietrich T, Dawson-Hughes B. Estimation of optimal serum concentrations of 25hydroxyvitamin D for multiple health outcomes. The American journal of clinical nutrition. 2006;84(1):18-28.PMID:16825677.

6. Penna G, Roncari A, Amuchastegui S, Daniel KC, Berti E, Colonna M et al. Expression of the inhibitory receptor ILT3on dendritic cells is dispensable for induction of CD4+Foxp3+ regulatory cells by 1,25-dihydroxy vitamin D3. Blood. 2005;106(10):3490-3497. https://doi.org/10.1182/blood-2005-05-2044 PMID:16030186.

7. Bouillon R, Bischoff-Ferrari H, Willett W. Vitamin D and health: perspectives from mice and man. J Bone Miner Res. 2008;23:974-979.

8. Manson JE, Brannon PM, Rosen CJ et al. Vitamin D deficiency-is there really a pandemic? New Engl J Med 2016;375(19):1817-1820.

9. Sahay M and Sahay R. Rickets-vitamin D deficiency and dependency. Indian J Endocrinol Metab. 2012;16(2):164-176.

10. Prietl B, Treiber G, Pieber TR et al. Vitamin D and immune function. Nutrients 2013;3(7):2502-2521

11. Shefin SM, Qureshi NK, Nessa A and Latif ZA. Vitamin D status among Bangladeshi adult Muslim females having Diabetes and using hijab. BIRDEM Med J. 2018;8(3):203-209.

12. Holick MF and Chen TC. Vitamin D deficiency: A worldwide problem with health consequences. Am J Clin Nutr. 2008;87(Suppl):1080S6S.

13. Heaney RP, Dowell MS, Hale CA and Bendich A. Calcium absorption varies within the reference range for serum 25-hydroxyvitamin D. J Am Coll Nutr. 2003;22:142-146.

14. Bonji S and Rafieian-Kopaei M. Vitamin D and its importance on public health. J parathyroid disease. 2016;4(1):20-24.

15. Moreno-Reyes R, Carpentier Y, Boelaert M, El-Moumni K, Dufourny G, Bazelmans C et al. Vitamin D deficiency and hyperthyroidism in relation to ethnicity: A cross sectional survey in healthy adults. Eur J Nutr. 2009;48:31-37.

16. Cannell JJ, Vieth R, Willett W, Zasloff M, Hathcock JN, White JH, et al. Cod liver oil, vitamin A toxicity, frequent respiratory infections and the vitamin D deficiency epidemic. Ann OtolRhinolLaryngol. 2008;117:864-870.

17. IOM report on calcium and vitamin D. Washington, DC: Institute of Medicine 2010. http://www.iom.edu/vitaminD.

18. Clifford J and Rosen, M.D. Vitamin D insufficiency. N Engl J Med 2011;364:248-254.

19. Fiscella K and Franks P. Vitamin D, race and cardiovascular mortality: Findings from a national US sample. Ann Fam Med. 2010;8;11-18. 


\section{REFERENCES}

20. Siddiqui A and Kamfar H. Prevalence of vitamin D deficiency rickets in adolescent school girls in Western region, Saudi Arabia. Saudi Med J. 2007;28:441-444.

21. Stodolska M and Livergood J. The influence of religion on the leisure behavior of immigration Muslims in the United States. Journal of Leisure Research. 2006;38:293-320.

22. Allali F, Archaoui S, Saoud B, Maaroufi H, Abouqal R and Hajjaj-Hassouni N. The impact of clothing style on bone mineral density among post-menopausal women in Morocco: A case-control study. BMC Public Health. 2006;6:153-147.

23. Allali F, FI-Aichaoui S, Khazani H, Benyahia B, Saoud B, EI-Kabbaj S, et al. High Prevalence of hypovitaminosis D in Morocco: Relationship to lifestyle, physical performance, bone markers and bone mineral density. Semin Arthritis Rheumo. 2009;38:444-451.

24. Mithal A, Wahl DA, Bonjour JP, Burckhardt P, Dawson-Hughes B, Eis-man JA, EI-Hajj Fuleihan G, Josse RG, Lips P and Morales-Torres J. Global vitamin D status and determinants of hypovitaminosis D. Osteoporos Int. 2009;20:1807-1820.

25. Jump up Mike Adams- vitamin D myths, facts and statistics- NaturalNews, January 1, 2005.

26. Van Dam RM, Snijder MB, Dekker JM, Stehouwer CD, Bouter LM, Heine RJ and Lips P. Potentially modifiable determinants of vitamin D status in an older population in the Netherlands: the Hoorn Study. Am J ClinNutr. 2007;85:755-761.

27. Nimri LF. Vitamin D status of female UAE college students and associated risk factors. J Public Health. 2018;40(3):e284-e290.

28. El-Hajj Fulcihan G. Vitamin D deficiency in the Middle East and its health consequences. Clin Rep Bone Miner Metabol. 2009;7:77-93.

29. IOM. Dietary reference intakes for Calcium and Vitamin D. Committee to Review Dietary Reference Intakes for Calcium and Vitamin D. Washington, DC: The Natural Academics Press. Institute of Medicine. 2011.

30. Ashahrani AA. Vitamin D deficiency and possible risk factors among Middle Eastern University students in London Ontario, Canada. Electronic Thesis and Dissertation Repository. 2014.

31. Lips P. Worldwide status of vitamin D nutrition. J Steroid Biochem Mol Biol. 2010;12:297-300.

32. Tripcovic I, Lambert H, Hart $\mathrm{K}$ et al. Comparison of vitamin D2 and vitamin D3 supplementation in raising serum 25-hydroxyvitamin D status: A systematic review and meta-analysis. Am J Clin Nutr. 2012;95:1357-1364.

33. Pal BR. Distribution analysis of vitamin D highlights differences in population subgroups: Preliminary observations from a pilot study in UK adults. J Endocrinol. 2003;179:119-129.

34. Gita R, Gupta A. Vitamin D deficiency in India: Prevalence, causalities and interventions. Nutr. 2014;6(2):729-775.

35. Akhtar S. Vitamin D status in South Asian populations-risks and opportunities. Crit Rev Food Sc Nutr. 2016;56(11):1925-1940. 